\title{
Relationship between Economic Value and Species \\ Diversity of Timber Resources in a Hill Forest in Peninsular Malaysia
}

\author{
A.G. Awang Noor \& I. Faridah-Hanum (Corresponding author) \\ Faculty of Forestry, Universiti Putra Malaysia \\ 43400 UPM Serdang, Selangor, Malaysia
}

Tel: 60-3-8946-7178Ｅ-mail: i.faridahhanum@gmail.com

\author{
T.I. Tuan Marina
}

Economic Unit, Forestry Department Peninsular Malaysia

Jalan Sultan Salahuddin, 50660 Kuala Lumpur Malaysia

The financial support for this project came from the Forestry Department Peninsular Malaysia through a consultancy project commissioned to the first two authors entitled "Economic Valuation and Forest Resource Accounting in Peninsular Malaysia".

\begin{abstract}
Timber resource is a major component of tropical forest and usually undervalued economically. This paper attempts to examine the relationship between economic value and species diversity of a hill dipterocarp forest in Peninsular Malaysia. The rank-abundance curve described a lognormal distribution pattern, indicating high diversity communities. The species diversity indices obtained were high: Fisher's alpha diversity index ranged from 96.53 to 109.56, Shannon-Weiner index were 5.29 to 5.39, while values of Simpson Index ranged from 134.02 to 151.11. The estimated mean stumpage value per hectare was Malaysian Ringgit RM25 413 and the main contribution was from the family Dipterocarpaceae. The regression analysis showed that the relationship between stumpage value and species diversity was not significant at the $5 \%$ level ( $>0.05)$. Timber volume, size of trees and the presence of high timber value have great influence on the stumpage value for a given forest area.
\end{abstract}

Keywords: Economic value, Species diversity index, Regression analysis, Residual value technique

\section{Introduction}

Malaysia's forest essentially comprise of an evergreen rainforest with sixteen different types of natural climatic and edaphic forests ranging from the coasts to mountains (MOSTE, 1997). Her species diversity is one of the richest in the world and its contribution is very significant for the socio-economic development of the country. The diversity of forest goods and services provides timber and non-timber goods in the forestry sector, food and industrial crops in the agriculture sector and the regulation of good water, air, temperature and carbon sequestration amongst others. The lowland and hill forests provide many valuable timber species and predominate the international tropical timber market.

Numerous descriptive studies of species richness in lowland and hill forests have been used to analyse structure and diversity. Generally, these studies relied on data from various plot sizes ranging from one to four hectares. The economic value of timber resources has also been extensively analysed and has covered many different types of forest ecosystems. Despite numerous studies, there has been little effort to examine the relationship between the economic value measured by stumpage value and species diversity of tropical forests. The aim of this paper was to show the kind of relationship between stumpage value and species diversity in a tropical hill forest. This study is part of an on-going larger project entitled "Economic Valuation and Forest Resource Accounting in Peninsular Malaysia" commissioned by the Forestry Department Peninsular Malaysia in 2006 to the Faculty of Forestry, Universiti Putra Malaysia to determine the economic value of forest resources for six forest ecosystems viz., montane forest, hill forest, lowland forest, peat swamp forest, mangrove forest and coastal forest. 


\section{Materials and Methods}

\subsection{Study Area}

This study was carried out in Tranum Forest Reserve, Pahang, Peninsular Malaysia during the year 2006. Five plots each of size 1 ha $(100 \mathrm{~m} \times 100 \mathrm{~m})$ were established along a line transect from altitude 350 to $880 \mathrm{~m}$ a.s.1. Plots $1,2,3,4$ and 5 were further divided into $10 \mathrm{~m} \times 10 \mathrm{~m}$ subplots for enumeration purposes. All trees greater than $1 \mathrm{~cm}$ dbh were measured and identified up to the specific level. The details of the plots' establishment are discussed in another paper (Faridah-Hanum et al., 2007).

\subsection{Species diversity}

Species abundance times quadrat matrices were prepared and then exported for each two combination plots (e.g. plots 1 $\& 2$, plots $1 \& 3$, etc) in order to calculate the means and variances of the species richness-estimators, based on 50 randomized quadrat orders for each data set. The program EstimateS was used to compute species richness-estimators (Colwell, 2006). The rank-abundance curve was then examined and plotted to describe the community structure based on the lognormal distribution model. The following formula were used to calculate various species richness and diversity indices (Waite, 2000):

a) Margalef's index of species richness: $\mathrm{R}=\left(\mathrm{S}_{\mathrm{obs}}-1\right) / \ln \mathrm{N}$, where $\ln \mathrm{N}$ is the natural $\log$ of the number of individuals inventoried, $\mathrm{S}_{\mathrm{obs}}$ is the total number of species recorded

b) Alpha Fisher's index of diversity: $\mathrm{S}=\alpha \ln (1+\mathrm{N} / \alpha)$

c) Shannon-Wiener index of diversity: $H^{\prime}=-\Sigma \mathrm{p}_{\mathrm{i}}^{*} \ln \mathrm{p}_{\mathrm{i}}$, where $\mathrm{p}$ is relative percentage cover value of species expressed as a proportion

d) Simpson's (inverse) index of diversity: $S=1 / \mathrm{D}$, where $\mathrm{D}$ is the sum of relative percentage (i.e. $\Sigma \mathrm{p}_{\mathrm{i}}$, that is the index of dominance), $\mathrm{D}$ ranges from $1-\mathrm{S}_{\mathrm{obs}}$ )

e) Pielou's measure of evenness: $\mathrm{E}=\mathrm{H}^{\prime} / \ln \mathrm{S}_{\mathrm{obs}}$

\subsection{Estimating Economic Value of Timber Species}

The economic value of timber resources i.e. standing tree is called stumpage value and can be calculated using the residual value technique. Stumpage value is calculated by taking the difference between the selling value of the products made from it and the stump-to-market processing costs (including margin for profit and risk) (Davis \& Johnson, 2000; Klemperer, 2003). The following formula is used to calculate stumpage value for each tree inventoried (Awang Noor et al., 1992; Awang Noor \& Mohd. Shahwahid, 1995):

$\mathrm{SVi}, \mathrm{j}=(\mathrm{Pi}, \mathrm{j}-\mathrm{C}-\mathrm{PMi}, \mathrm{j}) * \mathrm{Vi}, \mathrm{j} \quad$ where, $\mathrm{SV}$ is stumpage value per hectare $(\mathrm{RM}), \quad \mathrm{P}$ is ex-forest log price $(\mathrm{RM} / \mathrm{m} 3)$, $\mathrm{C}$ is logging cost $(\mathrm{RM} / \mathrm{m} 3), \mathrm{PM}$ is profit margin $(\mathrm{RM} / \mathrm{m} 3), \mathrm{V}$ is volume of standing tree $(\mathrm{m} 3), \mathrm{i}$ is index of species, $\mathrm{j}$ is the index of diameter class. The margin for profit and risk (PM) is computed as follows:

$\mathrm{PMij}=(\mathrm{Pij} * \mathrm{PR}) /(1+\mathrm{PR})$, where PR is profit ratio. The profit ratio used here was 0.3.

The total stumpage value is obtained by summing up the stumpage value for all individual trees in the study area, i.e.

$$
\text { Total SV }=\sum_{\mathrm{i}=1}^{\mathrm{n}} \sum_{\mathrm{j}=1}^{\mathrm{k}} \mathrm{SV}_{\mathrm{i}, \mathrm{j}}=\sum_{i=1}^{n} \sum_{j=1}^{k}\left[\left(\mathrm{P}_{\mathrm{i}, \mathrm{j}}-\mathrm{C}-\mathrm{PM}_{\mathrm{i}, \mathrm{j}}\right) * \mathrm{~V}_{\mathrm{i}, \mathrm{j}}\right]
$$

The volume of individual tree inventoried was estimated using local volume table developed by Awang Noor et al. (2001) and given as follows:

$$
\begin{gathered}
\mathrm{V}_{\mathrm{i}}=0.0015086^{*} \mathrm{DBH}_{\mathrm{i}}^{1.882311} \text {, where } \mathrm{V} \text { is volume of standing tree }\left(\mathrm{m}^{3}\right), \mathrm{DBH} \text { is tree } \mathrm{dbh} \text { and } i \quad \text { is } \\
\text { index of tree. }
\end{gathered}
$$

Data on log prices (in Malaysian Ringgit RM) by species and diameter classes were obtained from ASPA (2004) log price report. The ex-forest log prices per cubic meter were reported for individual species and species groups. The average logging cost used was RM120/ $\mathrm{m}^{3}$ and the profit ratio was 0.3 .

\subsection{Relationship Between Economic Value and Species Diversity}

The relationship between stumpage value and species diversity can be written as follows:

$S V_{i}=\alpha+\beta^{*} S D I_{i}+\varepsilon_{i}$, where $\mathrm{SV}$ is stumpage value (RM) in each quadrat $\mathrm{i}(20 \mathrm{~m} \mathrm{x} 20 \mathrm{~m})$, SDI is Shannon-Wiener diversity index (for all trees above $1 \mathrm{~cm}$ ), $\alpha$ and $\beta$ are parameters and $\varepsilon$ is random error with mean zero and common variance, $\varepsilon_{i} \sim N\left(0, \sigma^{2}\right)$. The estimated model was:

$$
S \hat{V}_{i}=\hat{\alpha}+\hat{\beta}^{*} S D I_{i}
$$


The model was estimated using the ordinary least square technique (OLS). Two situations were evaluated: (a) trees greater than $30 \mathrm{~cm} \mathrm{dbh}$, and (b) trees above the cutting limit $(50 \mathrm{~cm}$ for dipterocarps, and $45 \mathrm{~cm}$ for the non-dipterocarps). These are the minimum diameter cutting limits for trees to be harvested under the sustainable forest management (SFM) practices in Peninsular Malaysia.

\section{Results and Discussion}

\subsection{Species Diversity}

There were 22374 stems comprising 446 tree species included in 176 genera and 64 families identified from all the plots. Results on the floristic composition, tree families and species dominance were discussed in detail in a separate paper (Faridah-Hanum et al., 2007). The rank-abundance curve in Figure 1 describes a lognormal distribution pattern, indicating how varied the community was. The density dependent measures showed that the study area had high diversity in all plots (Table 1). The Fisher's alpha diversity index $(\alpha)$ range from 96.53 to 109.56 and the average for all plots is 102.27. The Shannon-Weiner index (H') gave a very high value ranging from 5.29 to 5.39; while the average for all five plots gave $H^{\prime}=5.36$. The values of $H^{\prime}$ increased with species but they rarely exceed 5.0 (Waite, 2000). The Simpson index (D) range from 134.02 to 151.11 and the average is 144.04 which is a measure of index of dominance and gives the probability that two individuals drawn randomly from a sample will belong to the same species. The distribution of the individuals among the species was even in all plots $(\mathrm{E}>0.9)$. The significant difference of the Shannon-Wiener index between two plots can be compared using the Student's t-test, which is given by (Waite, 2000) is shown in Table 2. The Shannon-Wiener index were not significantly different among plots 3,4 and 5 ( $>0.05$ ). All other comparisons of Shannon-Wiener index were found to be significantly different at the 5\% level $(\mathrm{p}<0.05)$.

\subsection{Economic Value}

It was found that the average stumpage value per ha for commercial trees above the cutting limit (trees above cutting limit: $\geq 50 \mathrm{~cm}$ for dipterocarps and $\geq 45 \mathrm{~cm}$ for non-dipterocarps) was RM 25413 per ha (Table 3). More than half (57\%) of the stumpage values was contributed by the family Dipterocarpaceae followed by Myristicaceae (11.1\%), Sapotaceae (7.7\%), Guttiferae (5.8\%) and Myrtaceae (4.1\%). This was due to the contribution by larger sized trees of three major species of the family Dipterocarpaceae which were Shorea platyclados, S. ovata and S. parvifolia which contributed about $47 \%$ of the total stumpage value per hectare (Table 4). For trees $\geq 30 \mathrm{~cm}$ the dipterocarps present contributed an average per ha of $66 \%$ of the total stumpage value (Table 5). The stumpage value also varied by diameter class. About half $(47 \%)$ of the total stumpage was from the diameter class $50-80 \mathrm{~cm}$. The results also indicated that higher diameter class had contributed the large proportion of stumpage value. This shows that in terms of economic value of timber resources, its contribution depends on the extent of the timber volume, the size of trees and the presence of high value timber. When compared to the stumpage value estimated from previous studies, the stumpage value estimated in this study site was relatively high and in most cases greater than the other forest areas (Table 6). This study hence proved that commercial sized trees gave a higher stumpage value.

\subsection{Relationship Between Economic Value and Species Diversity}

The scatter plot of stumpage value and one of the species diversity indices is shown in Figure 2. It can be seen that the relationship is positive but it is observed that a large variation of stumpage value exists as the diversity index increases. The large variation of stumpage value at higher values of diversity index might indicate the presence of heteroskedasticity in the sample (Gujarti, 2003). Using the Breusch-Pagan-Godfrey heteroskedasticity test of software STATA 8.0, we obtained the $\chi^{2}$ value of 0.92 at $5 \%$ level of significance. Therefore, we conclude that there was no heteroskedasticty of error variance $(\mathrm{p}>0.05)$ and the parameter estimates were done using the ordinary least square (OLS) method.

The results of the regression analysis for OLS are presented in Table 7. There is a positive relationship between stumpage value and species diversity in the study area for trees above $30 \mathrm{~cm}$ dbh and above the cutting limit. However, the variation of stumpage value is explained as a small percentage of species diversity ( 3 percent for trees greater than $30 \mathrm{~cm}$ and less than 1 percent for trees above the cutting limit). The coefficients of the regression indicate that an increase of one point of diversity index increases the stumpage value by Malaysian Ringgit RM456 and RM956 for trees $\geq 30 \mathrm{~cm} \mathrm{dbh}$ and $45 \mathrm{~cm} \mathrm{dbh,} \mathrm{respectively.} \mathrm{However,} \mathrm{the} \mathrm{regression} \mathrm{coefficients} \mathrm{in} \mathrm{the} \mathrm{two} \mathrm{dbh} \mathrm{situations}$ are not significantly different at $5 \%$ level $(\mathrm{p}>0.05)$. Therefore, the results of the study showed that the economic value of timber resources did not depend on species diversity in a hill forest. As mentioned in the preceding section, stumpage value depends on the extent of timber volume, the size of trees and the presence of high value timber not on whether the forest is highly diverse or has high species richness.

\section{Conclusion}

The Tranum Forest Reserve, Pahang shows both high species diversity and economic value. However, the results of regression analysis suggest stumpage value was not affected by species diversity. The low variation of this 
relationship is attributed to different factors affecting stumpage value and species diversity. While the stumpage value is affected by timber volume and market condition of log, species diversity is affected by many related factors such as historical factors of the area, spatial heterogeneity, competition, climatic, productivity and disturbance of the area. Further analysis is required to examine the relationship between economic value and species diversity under various market conditions. Incorporating economic and ecological perspectives in forest management will enhance sustainable forest management.

\section{References}

ASPA. (2006). Log Price Report May/2006. Amanah Saham Pahang, Peninsular Malaysia.

Awang Noor, A.G., Khamuruddun, M.N., Ashari, M., Mohd. Radhi, C.A., Azmi, N., Jefri, A.R., \& Mazlan, A. (2001). Analisis Awal Pembentukan Sifir Isipadu Setempat Bagi Hutan Dipterokarpa Pamah dan Bukit di Negeri Pahang. Laporan Kajian Penggubalan Sifir Isipadu Setempat Negeri Pahang. Jabatan Perhutanan Negeri Pahang (unpublished Report).

Awang Noor, A. G., Vincent, J.R., \& Yusuf, H. (1992). Comparative economic analysis of forest revenue systems in Peninsular Malaysia. Final report submitted to Osborn Center Forestry Policy Grants Program, Washington D.C.

Awang Noor, A.G., \& Mohd. Shahwahid, H.O. (1995). Estimation of stumpage values in three concession compartments of MUDA/PEDU watershed area. Paper presented at the First Workshop on "Kajian Kesan Pembalakan Terhadap Waduk Di Hutan Simpan Ulu Muda", 23 January, 1995, Universiti Teknologi Malaysia, Skudai, Johor..

Awang Noor, A.G., \& Mohd. Shahwahid, H.O. (2003). Forest Pricing Policy in Malaysia. Research Report No. 2003-RR2. Environment Economic Program for South East Asia, Singapore.

Che Roslan, C.D. (1996). Stumpage valuation in three logging blocks of Kelantan Timber Complex (KTC) Agreement Area. B.S. For. Thesis, Faculty of Forestry, Universiti Pertanian Malaysia. Serdang (unpublished).

Colwell, R. K. (2006). EstimateS: Statistical estimation of species richness and shared species from samples. Version 8.0. User's Guide and application. [Online] Available: http://purl.oclc.org/estimates (September 15, 2006)

Davis, L.S., \& Johnson, K.N. (2000). Forest management $\left(4^{\text {th }}\right.$ ed.). New York: McGraw Hill.

Dominic, E. (1995). Stumpage appraisal for timber concession in Johor, Malaysia. B.For.Sc. Thesis. Faculty of Forestry. Universiti Pertanian Malaysia. Serdang (unpublished).

Faridah-Hanum, I., Miskon, S., \& Awang Noor, A.G. (1999a). Tree species diversity and economic value of a watershed forest in Ulu Muda Forest Reserve, Kedah. Pertanika Journal of Agricultural Science, 22(1), 63-68.

Faridah Hanum, I., Pius, P., \& Awang Noor, A.G. (1999b). Economic Valuation of Tree Species Diversity in Ayer Hitam Forest, Selangor, Peninsular Malaysia. Pertanika Journal of Agricultural Science, 22(2), $167-170$.

Faridah-Hanum, I., Awang Noor A.G., \& Tuan Marina T.I. (2007). Stand structure and diversity of trees of tropical hill forest in Peninsular Malaysia. Paper Presented at the "Seminar on Economic Valuation of Forest Goods and Services 2007”, 16-17 December, 2007, Kuala Terengganu, Terengganu.

Gujarti, D.N. (2003). Basic econometrics $\left(4^{\text {th }}\right.$ Edition). New York: McGraw Hill.

Klemperer, W.D. (2003). Forest resource economics and finance. New York: McGraw Hill.

MOSTE. (1997). Assessment of biological diversity in Malaysia. Ministry of Science, Technology and Environment, Malaysia, Kuala Lumpur,

Nur Hajar, Z. S. (1999). Stumpage appraisal using tender price in Pahang. M.S. Thesis. Faculty of Forestry, Universiti Putra Malaysia, Serdang (unpublished).

Waite, S. (2000). Statistical ecology in practice. Harlow: Pearson Education Limited. 
Table 1. Diversity dependent measures for each 1-ha plot calculated based on tree density, Tranum Forest Reserve, Pahang (trees $\geq 1 \mathrm{~cm} \mathrm{dbh)}$

\begin{tabular}{|c|c|c|c|c|c|c|}
\hline $\begin{array}{l}\text { Diversity } \\
\text { dependent } \\
\text { measure }\end{array}$ & Plot 1 & Plot 2 & Plot 3 & Plot 4 & Plot 5 & Average All Plots \\
\hline $\mathrm{N}$ & 3924 & 3577 & 4952 & 5002 & 4919 & 4475 \\
\hline $\mathrm{S}_{\mathrm{obs}}$ & 360 & 355 & 388 & 421 & 417 & 388 \\
\hline Basal Area & 70.45 & 56.30 & 130.13 & 126.89 & 99.83 & 96.72 \\
\hline $\mathrm{R}$ & 43.38 & 43.26 & 45.49 & 49.31 & 48.94 & 46.08 \\
\hline$\alpha$ & $\begin{array}{l}96.53 \\
(2.89)\end{array}$ & $\begin{array}{l}97.93 \\
(3.02)\end{array}$ & $\begin{array}{l}98.56 \\
(2.74)\end{array}$ & $\begin{array}{r}109.56 \\
(2.97)\end{array}$ & $\begin{array}{r}108.78 \\
(2.97)\end{array}$ & 102.27 \\
\hline $\mathrm{H}^{\prime}$ & $\begin{array}{r}5.29 \\
(0.01) \\
\end{array}$ & $\begin{array}{r}5.33 \\
(0.01) \\
\end{array}$ & $\begin{array}{r}5.4 \\
(0.01) \\
\end{array}$ & $\begin{array}{r}5.38 \\
(0.01) \\
\end{array}$ & $\begin{array}{r}5.39 \\
(0.01) \\
\end{array}$ & 5.36 \\
\hline $\mathrm{S}$ & $\begin{array}{r}134.02 \\
(0.61)\end{array}$ & $\begin{array}{r}148.04 \\
(0.58)\end{array}$ & $\begin{array}{r}151.11 \\
(0.74)\end{array}$ & $\begin{array}{r}143.45 \\
(0.70)\end{array}$ & $\begin{array}{r}143.58 \\
(0.69)\end{array}$ & 144.04 \\
\hline $\mathrm{E}$ & 0.90 & 0.91 & 0.91 & 0.89 & 0.89 & 0.90 \\
\hline
\end{tabular}

Table 2. Results of t-tests for comparison of Shannon-Wiener Index among plots in Tranum Forest Reserve, Pahang (** significant at the $5 \%$ level; ns not significant at the $5 \%$ level)

\begin{tabular}{|c|c|c|c|c|c|}
\hline & Plot 1 & Plot 2 & Plot 3 & Plot 4 & Plot 5 \\
\hline Plot 1 & - & $-2.0 * *$ & $-5.5 * *$ & $-4.5 * *$ & $-5 * *$ \\
\hline Plot 2 & & - & $-3.5 * *$ & $-2.5 * *$ & $-3 * *$ \\
\hline Plot 3 & & & - & $1.0 \mathrm{~ns}$ & $0.50 \mathrm{~ns}$ \\
\hline Plot 4 & & & & - & $-0.50 \mathrm{~ns}$ \\
\hline Plot 5 & & & & & - \\
\hline
\end{tabular}


Table 3. Average stumpage value per hectare (RM/ha) by families in Tranum Forest Reserve, Pahang (trees above cutting limit: $\geq 50 \mathrm{~cm}$ for dipterocarp; $\geq 45 \mathrm{~cm}$ for non-dipterocarp)

\begin{tabular}{|c|c|c|}
\hline Family & Stumpage Value (RM) & Percentage \\
\hline Dipterocarpaceae & 14485 & $57.00 \%$ \\
\hline Myristicaceae & 2812 & $11.07 \%$ \\
\hline Sapotaceae & 1947 & $7.66 \%$ \\
\hline Guttiferae & 1453 & $5.72 \%$ \\
\hline Myrtaceae & 1041 & $4.10 \%$ \\
\hline Lauraceae & 462 & $1.82 \%$ \\
\hline Tiliaceae & 408 & $1.61 \%$ \\
\hline Thymelaeaceae & 307 & $1.21 \%$ \\
\hline Moraceae & 241 & $0.95 \%$ \\
\hline Polygalaceae & 241 & $0.95 \%$ \\
\hline Meliaceae & 192 & $0.75 \%$ \\
\hline Ebenaceae & 181 & $0.71 \%$ \\
\hline Anacardiaceae & 153 & $0.60 \%$ \\
\hline Burseraceae & 141 & $0.55 \%$ \\
\hline Fagaceae & 118 & $0.46 \%$ \\
\hline Rubiaceae & 102 & $0.40 \%$ \\
\hline Flacourtiaceae & 89 & $0.35 \%$ \\
\hline Icacinaceae & 86 & $0.34 \%$ \\
\hline Apocynaceae & 82 & $0.32 \%$ \\
\hline Leguminosae & 82 & $0.32 \%$ \\
\hline Euphorbiaceae & 78 & $0.31 \%$ \\
\hline Ulmaceae & 77 & $0.30 \%$ \\
\hline Rosaceae & 74 & $0.29 \%$ \\
\hline Proteaceae & 60 & $0.24 \%$ \\
\hline Verbenaceae & 57 & $0.23 \%$ \\
\hline Juglandaceae & 51 & $0.20 \%$ \\
\hline Araucariaceae & 45 & $0.18 \%$ \\
\hline Sapindaceae & 45 & $0.18 \%$ \\
\hline Elaeocarpaceae & 44 & $0.17 \%$ \\
\hline Podocarpaceae & 38 & $0.15 \%$ \\
\hline Symplocaceae & 36 & $0.12 \%$ \\
\hline Sterculiaceae & 28 & $0.11 \%$ \\
\hline Rhizophoraceae & 21 & $0.08 \%$ \\
\hline Ochnaceae & 21 & $0.08 \%$ \\
\hline Theaceae & 20 & $0.08 \%$ \\
\hline Myrsinaceae & 20 & $0.08 \%$ \\
\hline Magnoliaceae & 17 & $0.07 \%$ \\
\hline Pandanaceae & 14 & $0.05 \%$ \\
\hline Meliosmaceae & 10 & $0.04 \%$ \\
\hline Ericaceae & 10 & $0.04 \%$ \\
\hline Melastomataceae & 7 & $0.03 \%$ \\
\hline
\end{tabular}




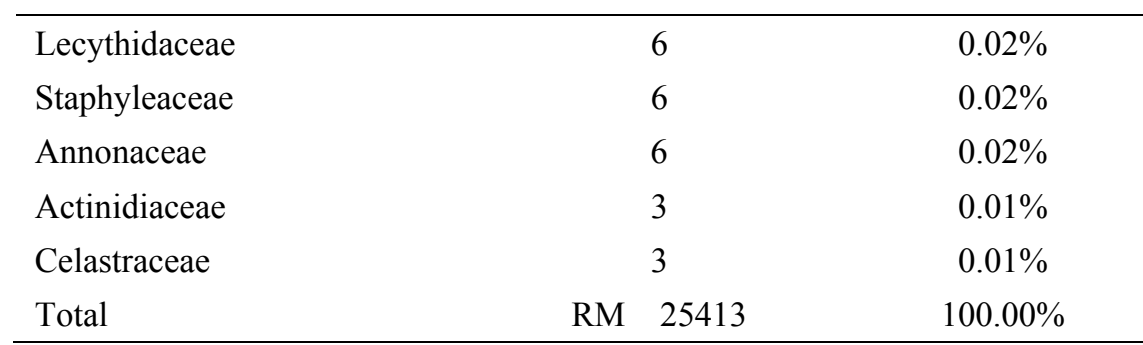

Table 4. Top 20 Most High Stumpage Value Timber Species (RM/ha), Tranum Forest Reserve, Pahang (trees above cutting limit: $\geq 50 \mathrm{~cm}$ dbh for dipterocarp; $\geq 45 \mathrm{~cm}$ dbh for non-dipterocarp)

\begin{tabular}{|c|c|c|c|}
\hline Species & Family & $\begin{array}{c}\text { Stumpage } \\
\text { Value Per ha }\end{array}$ & Percentage \\
\hline Shorea platyclados & Dipterocarp & 8254 & $32.5 \%$ \\
\hline Shorea ovata & Dipterocarp & 1905 & $7.5 \%$ \\
\hline Shorea parvifolia & Dipterocarp & 1807 & $7.1 \%$ \\
\hline Knema intermedia & Non-Dipterocarp & 1394 & $5.5 \%$ \\
\hline Dipterocarpus crinitus & Dipterocarp & 1303 & $5.1 \%$ \\
\hline Shorea maxima & Dipterocarp & 951 & $3.7 \%$ \\
\hline Payena dasyphylla & Non-Dipterocarp & 642 & $2.5 \%$ \\
\hline Calophyllum fraseri & Non-Dipterocarp & 557 & $2.2 \%$ \\
\hline Calophyllum symingtonianum & Non-Dipterocarp & 452 & $1.8 \%$ \\
\hline Pouteria malaccensis & Non-Dipterocarp & 418 & $1.6 \%$ \\
\hline Pentace curtisii & Non-Dipterocarp & 408 & $1.6 \%$ \\
\hline Knema scortechinii & Non-Dipterocarp & 368 & $1.4 \%$ \\
\hline Gonystylus maingayi & Non-Dipterocarp & 307 & $1.2 \%$ \\
\hline Horsfieldia crassifolia & Non-Dipterocarp & 279 & $1.1 \%$ \\
\hline Syzygium sp.12 & Non-Dipterocarp & 242 & $1.0 \%$ \\
\hline Palaquium sp. & Non-Dipterocarp & 231 & $0.9 \%$ \\
\hline Palaquium rostratum & Non-Dipterocarp & 195 & $0.8 \%$ \\
\hline Palaquium obovatum & Non-Dipterocarp & 161 & $0.6 \%$ \\
\hline Cratoxylum arborescens & Non-Dipterocarp & 155 & $0.6 \%$ \\
\hline Xanthophyllum palembanicum & Non-Dipterocarp & 143 & $0.6 \%$ \\
\hline \multirow[t]{3}{*}{ Subtotal } & All groups & 20,173 & $79 \%$ \\
\hline & Dipterocarp & $(14,221)$ & $(70 \%)$ \\
\hline & Non-dipterocarp & $(5,951)$ & $(30 \%)$ \\
\hline Remaining species & & 5,241 & $21 \%$ \\
\hline Total & & RM 25,413 & $100 \%$ \\
\hline
\end{tabular}


Table 5. Average stumpage value per hectare by diameter class and species group (RM/ha), Tranum Forest Reserve, Pahang (trees $\geq 30 \mathrm{~cm} \mathrm{dbh}$ )

\begin{tabular}{|l|c|c|c|c|c|c|}
\hline & \multicolumn{2}{|c|}{ Dipterocarp } & \multicolumn{2}{c|}{ Non-dipterocarp } & \multicolumn{2}{c|}{ Total } \\
\hline $\begin{array}{l}\text { Diameter } \\
\text { Class }\end{array}$ & $\begin{array}{c}\text { Stumpage } \\
\text { Value }\end{array}$ & Percentage & $\begin{array}{c}\text { Stumpage } \\
\text { Value }\end{array}$ & Percentage & Stumpage Value & Percentage \\
\hline $30-40$ & 1741 & $9.1 \%$ & - & - & 1741 & $6.0 \%$ \\
\hline $40-50$ & 2893 & $15.2 \%$ & 53 & $0.5 \%$ & 2946 & $10.2 \%$ \\
\hline $50-60$ & 3586 & $18.8 \%$ & 1752 & $17.6 \%$ & 5338 & $18.4 \%$ \\
\hline $60-70$ & 2559 & $13.4 \%$ & 1975 & $19.8 \%$ & 4534 & $15.6 \%$ \\
\hline $70-80$ & 2105 & $11.0 \%$ & 1810 & $18.2 \%$ & 3915 & $13.5 \%$ \\
\hline $80-90$ & 941 & $4.9 \%$ & 1165 & $11.7 \%$ & 2106 & $7.3 \%$ \\
\hline $90-100$ & 524 & $2.8 \%$ & 638 & $6.4 \%$ & 1162 & $4.0 \%$ \\
\hline $100-110$ & 1774 & $9.3 \%$ & 104 & $1.0 \%$ & 1878 & $6.5 \%$ \\
\hline $110>$ & 2934 & $15.4 \%$ & 2454 & $24.7 \%$ & 5389 & $18.6 \%$ \\
\hline Total & 19058 & $100.0 \%$ & 9951 & $100.0 \%$ & 29009 & $100.0 \%$ \\
\hline
\end{tabular}

Table 6. Estimated total stumpage value from previous studies in Peninsular Malaysia (RM/ha) (trees $\geq 30 \mathrm{~cm}$

\begin{tabular}{|c|c|c|c|c|c|}
\hline Forest Type & State & $\begin{array}{c}\text { Forest Reserve/ } \\
\text { Compartment }\end{array}$ & Year of study & $\begin{array}{c}\text { Average } \\
\text { stumpage } \\
\text { value per ha } \\
(\mathrm{RM} / \mathrm{ha})\end{array}$ & Source \\
\hline Hill Forest & Pahang & $\begin{array}{l}\text { Lesong FR/ } \\
\text { C88 \&89 }\end{array}$ & 1989 & 25,235 & $\begin{array}{l}\text { Awang Noor et al. } \\
(1992)\end{array}$ \\
\hline Hill Forest & Pahang & Bencah FR/C15 & 1989 & 11,200 & $\begin{array}{l}\text { Awang Noor et al. } \\
(1992)\end{array}$ \\
\hline Hill Forest & Pahang & Berkelah FR/C50 & 1999 & 12106 & Nur Hajar (1999) \\
\hline Hill Forest & Pahang & $\begin{array}{l}\text { Tekai Tembeling } \\
\text { FR/C77 }\end{array}$ & 2003 & 13,992 & $\begin{array}{l}\text { Awang Noor \& Mohd. } \\
\text { Shahwahid (2003) }\end{array}$ \\
\hline Hill Forest & Pahang & Lesong FR & 2003 & 42,532 & $\begin{array}{l}\text { Awang Noor \& Mohd. } \\
\text { Shahwahid (2003) }\end{array}$ \\
\hline Hill Forest & Kelantan & $\begin{array}{l}\text { Balah FR/Block } \\
95\end{array}$ & 1996 & 26,271 & Che Roslan (1996) \\
\hline Hill Forest & Terengganu & Jengai FR/C86 & 1989 & 17,172 & $\begin{array}{l}\text { Awang Noor et al. } \\
(1992)\end{array}$ \\
\hline Hill Forest & Kedah & $\begin{array}{l}\text { Ulu Muda } \\
\text { FR/C27 }\end{array}$ & 1994 & 26,710 & $\begin{array}{l}\text { Faridah-Hanum et al. } \\
(1999 a)\end{array}$ \\
\hline Hill Forest & Johor & Lenggor FR/C225 & 1994 & 23,038 & Dominic (1995) \\
\hline Lowland Forest & Selangor & Ayer Hitam FR/ & 1995 & 26,362 & $\begin{array}{l}\text { Faridah-Hanum et al. } \\
(1999 b)\end{array}$ \\
\hline Hill Forest & Pahang & $\begin{array}{l}\text { Tranum Forest } \\
\text { Reserve }\end{array}$ & 2006 & 28,962 & This study \\
\hline
\end{tabular}


Table 7. Results of regression analysis for stumpage value (SV) and Shannon diversity index (SDI) (ns - not significant at the $5 \%$ level)

\begin{tabular}{|l|c|c|c|}
\hline Variable & Parameter & Trees $\geq 30 \mathrm{~cm} \mathrm{dbh}$ & Trees above cutting limit \\
\hline (constant) & $\hat{\alpha}$ & $\begin{array}{c}-3419.766 \mathrm{~ns} \\
(2555.561)\end{array}$ & $\begin{array}{c}-1309.244 \mathrm{~ns} \\
(2057.498)\end{array}$ \\
\hline SDI & $\hat{\beta}$ & $\begin{array}{c}954.503 \mathrm{~ns} \\
(574.312)\end{array}$ & $\begin{array}{l}455.856 \mathrm{~ns} \\
(462.761)\end{array}$ \\
\hline N & 93 & 110 \\
\hline R square & 0.029 & 0.009 \\
\hline F value & $2.762 \mathrm{~ns}$ & $0.928 \mathrm{~ns}$ \\
\hline
\end{tabular}

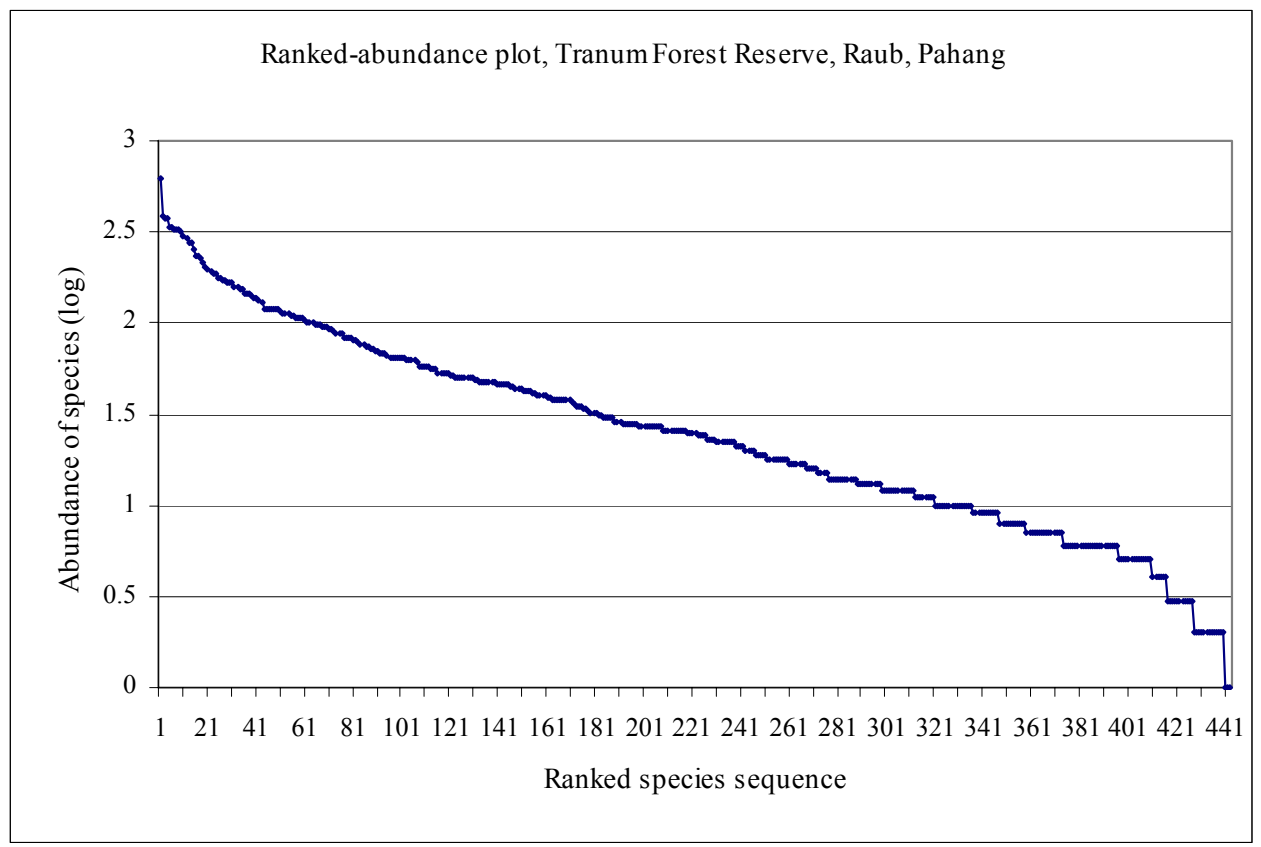

Figure 1. Ranked-abundance plot, Tranum Forest Reserve, Pahang (trees $\geq 1 \mathrm{~cm}$ dbh) 


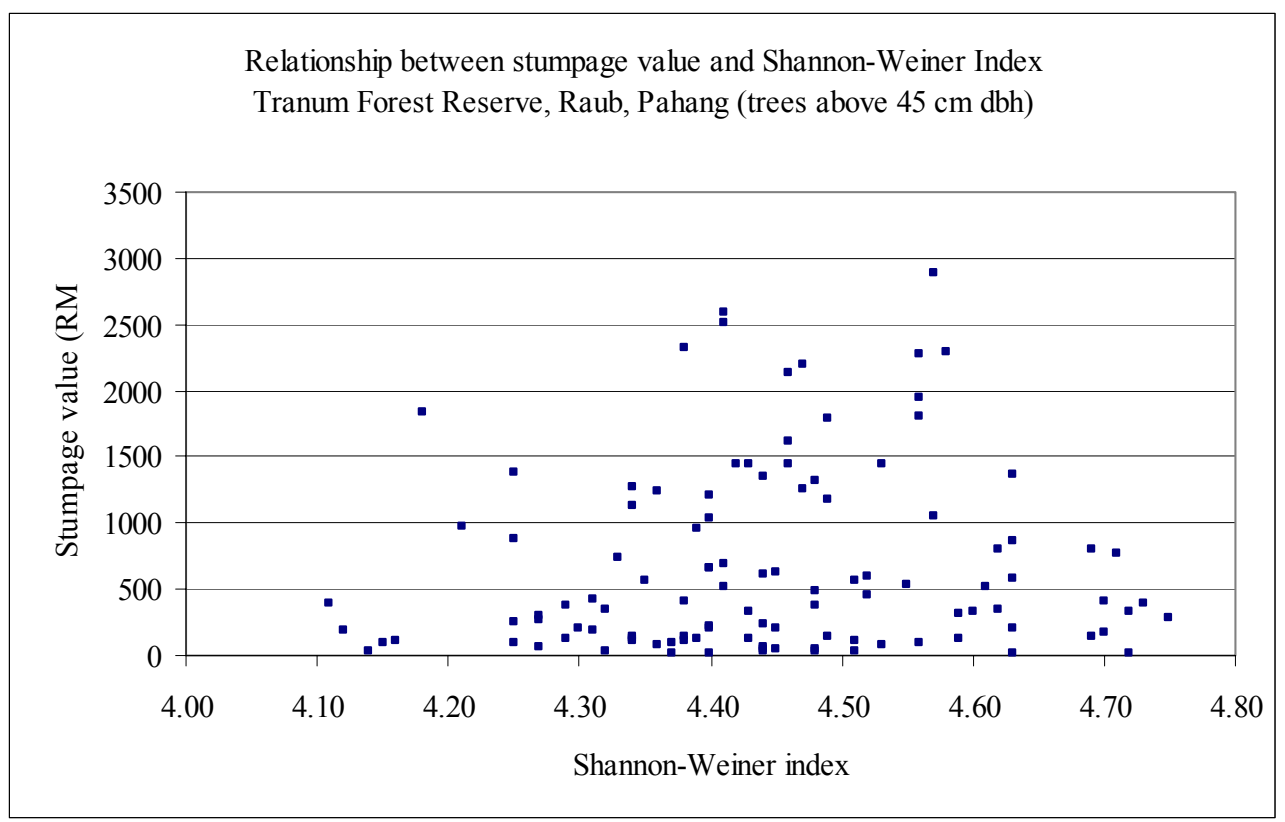

Figure 2. Relationship between stumpage value and Shannon-Wiener Index, Tranum Forest Reserve,

Pahang (trees $\geq 45 \mathrm{~cm} \mathrm{dbh)}$ 